\title{
Establishment of Integrated Evaluation Index System Based on Influence factors of Port Economy
}

\author{
Chun Deng ${ }^{1, a}$ and Guoliu $\mathrm{Hu}^{2}$, a \\ ${ }^{1}$ Hainan Radio \& TV University Haikou 570208, Hainan China \\ ${ }^{2}$ Hainan University Haikou 570208, Hainan China \\ a847549719@qq.com
}

Keyword: Port economy; Influence factor; Indicator system; Construction

\begin{abstract}
The port comprehensive evaluation index system are drawn from economic five impact factors of the port economy : Port infrastructure conditions, management ability, port hinterland economy condition, the service chain upper stream development condition and selected 12 indicators port development potential: The port cargo throughput, port berth and berth for production quantity, the total gross industrial output value of GDP for the port municipal city, consisting of the second industry and the tertiary industry output value, GDP growth rate for port city of investment in fixed assets, ports, financial institutions loan balance, total import and export of foreign trade, foreign investment and the total income of post and telecommunication of the port city.
\end{abstract}

\section{港口经济影响因素综合评价指标体系的构建}

\author{
邓春 ${ }^{1, a}$, 胡国柳 ${ }^{2, a}$ \\ 1. 海南广播电视大学, 中国海南海口 570208 \\ 2. 海南大学, 中国 海南 海口 570208 \\ a847549719@qq.com
}

摘要: 该港口经济影响因素综合评价指标体系是从影响港口经济的五大类因素: 港口的基础 设施条件、港口经营服务能力、港口腹地经济条件、产业链上游发展状况和港口发展潜力中 遴选出的 12 个指标: 港口货物吞吐量、港口泊位总长度、港口生产用泊位数量、港口所在城 市 GDP、港口所在城市第二产业总产值、港口所在城市第三产业总产值、港口所在城市 GDP 增长率、港口所在城市固定资产投资总额、港口所在城市金融机构贷款余额、港口所在城市 外贸进出口总额、港口所在城市外商投资实际到位总额和港口所在城市邮电通信收入所构成 的。

关键词：港口经济；影响因素；指标体系；构建

\section{1. 引言}

因子分析法是常用的港口经济影响因素综合评价方法。运用因子分析法进行实证研究的前提 条件是必须有一套完整的、全面的、适用的综合评价指标体系, 本文从港口经济主要影响因 素中选择了 12 个指标, 构建了一套独特而完整的港口经济影响因素综合评价指标体系, 为相 关研究者提供参考和帮助。

\section{2. 影响港口经济发展的因素}

港口经济是以港口为中心, 港口城市为载体, 综合物流运输体系为动脉, 腹地资源为依托, 相关的政策和国际合作环境为支持，为了实现区域之间相互联系、有机结合、共同发展，进 
而共同繁荣的外向型经济。影响港口经济发展的因素来自各个方面, 特别是近年来国际贸易 不断发展, 出现了很多促进港口经济发展的有利因素, 同时也有很多因素制约着港口经济的 发展。本文从港口经济的一般定义出发, 将影响港口经济发展的因素归为以下五大类:

2.1. 港口的基础设施条件

港口是港口经济发展的中心和基础, 港口的选择以及其后天建设是决定其能否发展成为国际 知名港口的先决条件。鉴于影响港口经济发展的基本因素是港口的自身条件和其后天的建设 程度，因此，本文将港口自身的条件和发展程度定为港口经济发展的一个基本影响因素，而 港口的自身条件中首推港口的基础设施条件：自然因素和硬件设施。

2.1.1 自然因素

自然因素中首推港口的地理区位条件。货主对港口的选择考虑的一个重要因素是总体服务成 本，而总体服务成本中的一个重要组成部分是货物由出发地到港口的运输成本或者是港口到 目的地的运输成本。我国虽然地域辽阔，但是对外贸易大量集中在沿海地区，如果港口靠近 经济发达地区, 靠近铁路、公路、水路、管道和航空等交通枢纽, 这样货主的运输成本会大 大降低, 有利于港口对腹地货源和中转货源这两个主要货源的争夺; 相反, 如果港口位置远 离腹地货源和中转货源，在其他条件相同的情况下，同其他港口竞争货源将处于较大的劣势 地位。比如上海港, 其既靠近经济发达、进出口贸易强劲的长江三角洲腹地, 又靠近我国水 运、铁路、公路的交通枢纽上海, 其在地理区位条件上具有明显的优势。另外, 是否靠近国 际航线对中转港而言往往比是否靠近内陆腹地更加重要。世界著名中转港口新加坡港就是一 个绝佳的例证, 虽然其内陆腹地十分有限, 但是其绝佳的靠近国际航线的区位条件是其成功 的一个主要原因。因此, 港口与腹地货源的距离以及港口与国际航道的距离是两个影响港口 经济的重要因素。

其次是港口的深水岸线和深水泊位资源。目前船舶的大型化趋势越发加快, 集装箱船舶已经 发展到第六代, 其对泊位水深的要求已达到 14.5 米, 而天然优良的深水岸线是建造这些深 水泊位的先决条件。缺乏深水岸线和深水泊位的港口则很难发展成为枢纽港或者干线港, 如 广州港曾是珠三角地区发展最快最早的港口, 但是由于缺乏深水泊位, 曾一度被深圳港超越,

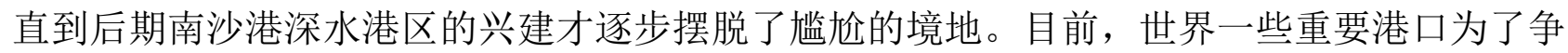
夺枢纽港地位，在其规划中也都以第五代、第六代集装箱为标准，建造 14 米以上甚至更深的 深水泊位。

最后是港口的气候条件。我国北方港口冬季容易受到冰冻天气的影响，南方港口夏季则容易 受到台风天气或者大雾天气的影响, 这都将影响港口的运营作业。

2. 1.2 港口硬件设施

港口硬件设施条件是港口运作的基础，其水平的高低直接影响港口的基本服务能力和水平。 硬件设施包括港口泊位、岸边装卸机械数量、堆场面积、库场容量和集卡数量、铁路条数、 驳船数量等等。反映了港口装卸设备能力、仓储设备能力、机械作业效率以及设备能力充足 程度。现实中, 这些硬件设施因素直接关系到车船在港停留的时间, 进而影响到运输总时间。 硬件设施中最主要的指标是泊位的数量和大小。拥有港阔水深的优质深水码头泊位在集装箱 船大型化越来越明显的今天显得尤为重要。港口的码头岸线越长、泊位数量越多、深水泊位 的数量越多, 能同时停靠的船舶就会越多, 这将降低港口的拥挤程度, 提高港口运作的效率, 从而提高港口经济效益; 其次是港口库场面积。港口库场是货物的主要集散场所, 直接影响 货物周转和车船停靠时间。库场面积与港口吞吐量及装卸效率密切相关, 同时库场有效面积 又与装卸效率互相影响。比如对于集装箱来说, 如果堆场的集装箱层数过高, 将影响港口的 装卸效率, 也给整个港口的作业带来不利影响。堆场有效面积越大, 港口作业的空间也就越 大，作业能力也就更强; 最后是港口的机械设备。现代港口越来越倾向于机械化和自动化运 作, 先进的港口机械是提高港口装卸效率的重要条件, 也就成为提高港口经济效益的重要因 素。

2.2. 港口经营服务能力 
港口的经营服务能力主要包括二个方面。首先是港口的货物吞吐量和集装箱吞吐量。港口货 物吞吐量和集装箱吞吐量直接反映了港口的生产能力, 是衡量港口竞争力的最重要的指标, 吞吐量的大小反映了港口的营业收入规模和利润规模, 吞吐量的增长率则反映了港口竞争能 力以及发展潜力。

其次是港口的航线数量。航线数量直接影响通过该港口将货物运输到的地方多少, 加强对外 联系，促进对外贸易，从而提高港口经济的竞争力。

2.3. 港口腹地经济条件

腹地的经济资源是港口经济发展的依托，腹地经济发展越好就越能够为港口经济的发展提供 支持，将腹地的服务与产品运送到世界各地，因此，港口腹地的经济发展水平直接影响港口 的发展现状和前景。国内的众多大港一般都是背靠重要的腹地经济得以发展的, 比如上海港 和宁波一舟山港背靠发达的长江三角洲经济区, 深圳港背靠发达的珠江三角洲经济区, 天津 港背靠日益发达的环渤海经济区。

港口腹地经济包括两方面的内容。首先是港口所在城市的经济发展水平。港口的发展离不开 为之提供支持的城市, 港口与港口城市联系紧密, 相互促进。港口城市的发展为港口提供充 足的建设资金和人力资源, 港口经济的提升能更好的促进港口城市经济的繁荣, 因此, 很多 港口城市经济发达，对外贸易繁盛，成为世界上或国内的重要城市如荷兰的鹿特丹。港口所 在城市的 GDP 一般与港口的吞吐量都成正相关，港口城市的进出口总额与港口的吞吐量密切 相关，同时港口所在城市的二、三产业比重和规模都间接影响当地港口的吞吐量和营收能力。 在我国, 经济自改革开放后发生了很大变化, 经济格局也出现重大变动, 沿海地区特别是沿 海港口城市成为了重要的进出口基地, 因此, 沿海所在城市的经济规模和经济结构极大的影 响港口的发展。港口所在城市的进出口贸易一般都相当发达, 比如深圳市占据了珠江三角洲 地区的大部分进出口贸易额。

其次是港口的腹地范围。腹地是港口的直接货源来源地和目的地, 腹地的经济发展水平直接 影响港口的吞吐量和竞争能力, 腹地的范围越大、GDP 越高、进出口额越高, 那么腹地的物 流、商流也就越发达, 对港口的服务需求就越大。

2.4. 产业链上游发展状况

港航产业链的枢纽是港口, 其上游主要包括了为现代国际航运提供融资保险、海事仲裁、海 事规范、海事咨询、国际性航运交易、技术标准等非航运直接经营业务的服务内容，是现代 航运服务产业中最为重要的部分。航运业是资金密集型行业，在基础设施建设、船舶制造、 航运管理与交易等各方面均需要巨大的资金投入，金融服务业对航运业的发展起到十分重要 的支撑作用。所以经济成分中金融和保险业的运行情况具有一定的代表性，港口经济上游产 业的支撑是提高其竞争力的必要条件。

2.5. 港口发展潜力

港口发展潜力直接影响港口经济未来的竞争力。首选是临港产业发展状况。鉴于临港产业发 展的重要性提升, 以外商投资为主的加工出口业等各种港口城市产业发展对港口的进出口产 生巨大影响, 因此, 港口所在城市的外商投资数额深刻反映和影响港口的进出口。我国经济 起飞的初期, 以港台投资为主的加工贸易占据着大量的进出口贸易, 比如深圳富士康等, 富 士康在河南的投资曾使河南的对外贸易翻倍。因此，外商对某一地区的投资直接影响进出口 规模和格局, 也将加大影响港口的发展和竞争。

其次是港口物流业的发展。在现代贸易中, 物流占据了越来越重要的位置, 一流的物流服务 可以带来港口经济更好的发展, 因为港口经济的发展不仅需要良好的港口建设, 还需要便利 的交通运输和流畅的物流服务, 从而可以带动港口经济快速向前发展。集疏运体系完善程度, 主要指连通港口的物流硬件建设情况, 包括公路、铁路和内河交通的密集畅通情况, 以及各 种物流园区的建设情况; 物流的便捷程度, 反映的是港口物流业支持港口发展的实际能力, 包括货物的周转速度情况, 以及为物流服务的信息化水平提供支持的信息产业 (以邮电通信业 指标反映) 等。 
最后来至宏观环境, 港口经济不仅仅是在一个区域内的经济发展, 更是全球范围内的经济发 展。港口经济是经济全球化形势下国际贸易发展的产物, 它的发展需要各个区域内的经济协 调, 因此, 宏观环境也制约港口经济的发展。港口的宏观环境主要指政府对港口的政策法规 支持、政府给予港口人才的发展规划以及国际合作程度（用以说明港口参与国际合作的积极 程度，包括该区域的国际化和一体化程度）等。

\section{3. 指标体系的构建}

根据前文阐述, 本文构建港口经济影响因素综合评价体系, 选择 12 个指标作为影响港口经济 的主要因素, 突出了经济因素的影响力。如下表:

表 1 港口经济影响因素评价指标体系

\begin{tabular}{|c|c|}
\hline 一级指标 & 二级指标 \\
\hline 港口服务能力 & 港口货物吞吐量（万吨） \\
\hline \multirow{2}{*}{ 港口基础设施条件 } & 港口泊位总长度（米） \\
\hline & 港口生产用泊位数量（个） \\
\hline \multirow{4}{*}{ 港口腹地经济条件 } & 港口所在城市 GDP（亿元） \\
\hline & 港口所在城市第二产业总产值（亿元） \\
\hline & 港口所在城市第三产业总产值（亿元） \\
\hline & 港口所在城市 GDP 增长率（\%） \\
\hline \multirow{2}{*}{ 产业链上游发展状况 } & 固定资产投资（亿元） \\
\hline & 金融机构贷款余额（亿元） \\
\hline \multirow{3}{*}{ 港口发展潜力 } & 港口所在城市外贸进出口总额 (亿美元) \\
\hline & 港口所在城市外商投资实际到位总额 (亿美元) \\
\hline & 港口所在城市邮电通信收入（亿元） \\
\hline
\end{tabular}

\section{参考文献}

[1] 孟秀娟, 杨文娟. 基于因子分析的厦门港口竞争力研究 [J]. 物流工程与管 理, 2010, 40 (9) 52-55.

[2] 张菁菁. 基于因子分析法的西南港口竞争力评价 [J]. 物流工程与管 理, 2013, 31 (10) 35-38.

[3] 宋建明, 王海燕. 沿海港口经济贡献定量评价方法 [J]. 中国水运，2014, 52 (5) 23-25.

[4] 韩亮. 基于系统动力学的港口经济外部性研究 [D]. 大连海事大学, 2011, p. 25-29.

[5] 张晓宇. 港口物流与区域经济的互动分析 [D]. 大连海事大学, 2014, p. 36-39.

[6] 黄耀.港口物流产业集群与港口经济发展的关系研究 [D]. 重庆工商大学, 2014, p. 29-35.

[7] 唐妙言. 试论港口物流的价值分析 [J]. 经营管理者，2014, 66 (33) 53-56.

[8] 蔡素丽. 港口物流与经济增长关系分析 [J]. 长沙大学学报, 2015, 28 (02) 76-79.

[9] http://baike.baidu.com

[10]http://www.chinaports.com 


\section{Acknowledgements}

Hainan philosophy and social science planning 'To Develop Port Economy of Hainan Province

Boosting Maritime Silk Road_-Studies of Strategies of Port Economic Development in Hainan

Province' (HNSK (YB ) 15-66) .Person in charge: Chun Deng.

\section{References}

[1] Meng Xiu-juan, Yang Wen-juan: "Xiamen port competitiveness research based on factor analysis" [J]. Logistics Engineering and Management, Vol. 40(2010), No.9, p.52-55 (in Chinese)

[2] Zhang Jing-jing: "Southwest of port competitiveness evaluation based on factor analysis method" [J]. Logistics Engineering and Management, Vol. 31(2013), No.10, p.35-38 (in Chinese)

[3] Song Jian-ming, Wang Hai-yan: "Coastal ports quantitative evaluation method of economic contribution”'[J]. China Water Transport, Vol. 52(2014), No.5, p.23-25 (in Chinese)

[4] Han Liang: Port economic externality research based on system dynamics (MS., Dalian Maritime University, China 2011), p.25-29.

[5] Zhang Xiao-yu: The interaction between port logistics and regional economic analysis (MS., Dalian Maritime University, China 2014), p.36-39.

[6] Huang Yao: The port logistics industry cluster and the relationship between economic development research (MS., Chongqing Technology and Business University, China 2014), p.29-35.

[7] Tang Miao-yan: "Try to talk about the value of the port logistics analysis" [J]. Manager Joumal , Vol. 66(2014), No.33, p.53-56 (in Chinese)

[8] Cai Shu-li: "The port logistics and economic growth relationship analysis" [J]. Joumal Changsha, University, Vol. 28(2015), No.02, p.76-79 (in Chinese)

[9] Information on http://baike.baidu.com

[10] Information on http://www.chinaports.com

作者简介: 邓春, 女, 海南广播电视大学财经学院副院长、副教授, 研究方向: 产业经济。 胡国柳, 男, 会计学博士, 海南大学经济与管理学院院长、教授。 